\title{
GMR
}

\section{Effects of Moquiniastrum polymorphum ssp floccosum ethnolic extract on colorectal carcinogenesis induced by 1,2-dimethylhydrazine}

\author{
S.M.A. Limeiras ${ }^{1,2}$, B.C. Oliveira ${ }^{1}$, L.R. Pessatto ${ }^{1,3}$, J.R. Pesarini ${ }^{1,2}$, \\ C.A.L. Kassuya ${ }^{4}$, A.C.D. Monreal ${ }^{3}$, W.B. Cantero ${ }^{1,2}$, R. Antoniolli-Silva ${ }^{1,2}$, \\ A.C.M.B. Antoniolli-Silva ${ }^{1,2}$, M.E.A. Stefanello ${ }^{5}$ and R.J. Oliveira ${ }^{1,2,3}$ \\ ${ }^{1}$ Centro de Estudos em Célula Tronco, Terapia Celular e Genética Toxicológica, \\ Hospital Universitário Maria Aparecida Pedrossian, \\ Empresa Brasileira de Serviços Hospitalares, Campo Grande, MS, Brasil \\ ${ }^{2}$ Programa de Pós-Graduação em Saúde e Desenvolvimento na Região Centro-Oeste, \\ Faculdade de Medicina "Dr. Hélio Mandetta", \\ Universidade Federal de Mato Grosso do Sul, Campo Grande, MS, Brasil \\ ${ }^{3}$ Programa de Pós-Graduação em Farmácia, \\ Centro de Ciências Biológicas e da Saúde, \\ Universidade Federal de Mato Grosso do Sul, Campo Grande, MS, Brasil \\ ${ }^{4}$ Faculdade de Ciências da Saúde, Universidade Federal da Grande Dourados, \\ Dourados, MS, Brasil \\ ${ }^{5}$ Departamento de Química, Universidade Federal do Paraná, Curitiba, PR, Brasil \\ Corresponding author: R.J. Oliveira \\ E-mail: rodrigo.oliveira@ufms.br
}

Genet. Mol. Res. 16 (1): gmr16019518

Received November 4, 2016

Accepted January 30, 2017

Published March 16, 2017

DOI http://dx.doi.org/10.4238/gmr16019518

Copyright $(2017$ The Authors. This is an open-access article distributed under the terms of the Creative Commons Attribution ShareAlike (CC BY-SA) 4.0 License.

ABSTRACT. The objective of this study was to evaluate the effect of
Moquiniastrum polymorphum ssp floccosum ethanolic extract (MPEE)
on 1,2 dimethylhydrazine (DMH)-induced colorectal carcinogenesis in
mice. Forty-two male Swiss mice (Mus musculus) were subdivided into
six groups ( $\mathrm{N}=7$ /group): negative control, DMH, MPEE, pre-treatment,

Genetics and Molecular Research 16 (1): gmr16019518 
simultaneous, and post-treatment. Results showed that MPEE has antigenotoxic potential on the tested protocols pre- and silmultaneous treatment, and the percent damage reductions (\%DRs) were 81.88 and $93.12 \%$, respectively. The micronucleus test demonstrated that MPEE has great antimutagenic activity, with \%DRs higher than 77.09 in the associated groups. The aberrant crypt focus assay demonstrated anticarcinogenic potential of MPEE as the associated groups showed $\%$ DRs that ranged from 62.13 to $95.14 \%$. The study shows that MPEE is nontoxic and has chemopreventive and anticarcinogenic activity, thus it may prove to be a promising medicinal plant in view of its demonstrated properties.

Key words: Anticarcinogenicity; Comet assay; Micronucleus assay; Phagocytosis; Aberrant crypt focus

\section{INTRODUCTION}

According to the World Health Organization (WHO, 2016), 14 million people are currently estimated to have cancer in the world, and 8.2 million people die annually as a result of the disease.

The literature data show the relationship between cancer and inflammation (Diniz et al., 2012; Hu et al., 2015). Among the inflammation-induced cancers, the colorectal cancer ranks third among the most common malignant neoplastic diseases and comes fourth in cancerrelated mortality (Labianca et al., 2013). This type of neoplasia is prevalent in industrialized and Western countries, and is growing in Asian countries, where historically the risk of the disease was low (West et al., 2012; ACS, 2016).

The Brazilian National Cancer Institute (Instituto Nacional do Câncer - INCA, 2016) estimated 34,280 new cases of colorectal cancer to occur in Brazil in 2016. These data demonstrate the high prevalence of the disease, which foster studies correlating the country's biodiversity of plants with ethnobotanical knowledge in search of new anticancer compounds.

Moquiniastrum polymorphum, previously identified as Gochnatia polymorpha and popularly called cambará, belongs to the Asteraceae family (David et al., 2014). Studies show that the plant is rich in sesquiterpene lactones, sesquiterpenes, diterpenes, triterpenes, flavonoids, coumarins, phenolic compounds, and essential oils (Strapasson et al., 2012).

The cambará leaves, flowers and barks are widely used in the popular medicine as an infusion, especially for the treatment of respiratory tract inflammation, and infections (Bueno et al., 2005; Arambarri et al., 2008; Pionerdo et al., 2011). The anti-inflammatory activity of cambará ethanolic extract stem has also been reported in Swiss mice, as well as the 11,13-dihydrozaluzanin C isolated compound (Pionerdo et al., 2011). Later on, tests with female Swiss mice also demonstrated that the extract is neither mutagenic nor teratogenic. This finding was possible by means of the micronucleus assay and because no embryotoxicity was observed in experiments with pregnant mice.

The effective anti-inflammatory activity was also demonstrated by the paw edema test induced by Freund's complete adjuvant (CFA) (David et al., 2014). Finally, our research group described the antineoplastic activity of this extract, its fractions, and isolated compounds in both in vitro and in vivo assays (Strapasson et al., 2012; Martins et al., 2015). The in vivo

Genetics and Molecular Research 16 (1): gmr16019518 
assays revealed that the dichloromethane fraction of this medicinal plant reduces the growth of Walker 256 carcinosarcoma (Martins et al., 2015).

Given the above, the present study evaluated the effects of the M. polymorphum ethanolic extract (MPEE) stem for the action on the genetic integrity and splenic phagocytosis, and its ability to inhibit the formation of aberrant crypt foci in the intestinal mucosa of Swiss mice.

\section{MATERIAL AND METHODS}

\section{Collection and identification of botanical material}

The trunk barks of $M$. polymorphum ssp floccosum, naturally occurring in Curitiba, PR, were collected in May 2011. The plant was identified by Prof. Dr. Armando Carlos Cervi (Department of Botany - UFPR). A botanical voucher was deposited in the herbarium of the same institution under No. 30100.

\section{Preparation of the MPEE}

The barks were dried at $40^{\circ} \mathrm{C}$, milled and extracted three times with $95 \%$ ethanol (500 $\mathrm{mL}$ per $100 \mathrm{~g}$ of material) at room temperature, with solvent changed every $24 \mathrm{~h}$. The solutions were combined and the solvent evaporated under reduced pressure, providing the crude extract in a $3 \%$ yield in relation to the dry initial weight.

The M. polymorphum ssp floccosum was diluted in a hydroalcoholic solution with $1.2 \%$ ethanol $95^{\circ} \mathrm{GL}$ at a concentration of $100 \mathrm{mg} / \mathrm{kg}$ body weight (b.w.), and administered by oral gavage. This dose was chosen for having effective anti-inflammatory activity; higher doses do not indicate benefits for use (Piornedo et al., 2011; David et al., 2014).

\section{Chemicals}

The DNA damage-inducing and cancer-promoting agent 1,2-dimethylhydrazine (DMH, CAS No. 306-37-6; Sigma-Aldrich, St. Louis, MO, USA) was diluted in a $0.37 \mathrm{mg} /$ $\mathrm{mL}$ ethylenediaminetetraacetic acid (EDTA) solution and administered intraperitoneally (ip) to animals following a modified version of the protocol of Rodrigues et al. (2002). DMH was administered in 4 doses of $35 \mathrm{mg} / \mathrm{kg}$ b.w. twice weekly for 2 weeks. Four applications of DMH, twice weekly for 2 weeks, were used to induce aberrant crypt foci (Pesarini et al., 2013).

\section{Animals}

A total of 42 male Swiss mice (Mus musculus) in reproductive age were used. The animals were obtained from the Central Vivarium of the Center for Biological and Health Sciences, Federal University of Mato Grosso do Sul (Centro de Ciências Biológicas e da Saúde, Universidade Federal de Mato Grosso do Sul - CCBS/UFMS) and the experiment was conducted in the Biocapri Laboratory vivarium (CCBS/UFMS).

The animals were housed in propylene boxes covered with wood shavings and were fed commercial feed $\left(\mathrm{Nuvital}^{\circledR}\right)$ and filtered water ad libitum. The animals were maintained at controlled temperature $\left(22^{\circ} \pm 2^{\circ} \mathrm{C}\right)$ and humidity $(55 \pm 10 \%)$ on a ventilated cage rack $\left(\right.$ Alesco ${ }^{\circledR}$ e520) with a photoperiod of 12-h light/12-h dark.

Genetics and Molecular Research 16 (1): gmr16019518 
The experiment was conducted according to the guidelines of the Brazilian College of Animal Experimentation, and approved by the Federal University of Mato Grosso do Sul Ethics Committee on Animal Use (Protocol No. 401/2012).

\section{Experimental design}

The animals were divided into six groups ( $\mathrm{N}=7$ /group): negative control, $\mathrm{DMH}$, MPEE, pre-treatment, simultaneous, and post-treatment. The experimental period comprised 12 weeks. The animals of the negative control group were treated with hydroalcoholic solution orally ( $p o$ ) every day until the twelfth week; in the third and fourth weeks two doses of EDTA solution (ip) were administered.

The animals of the DMH group (positive control group) received hydroalcoholic solution ( $p o$ ) until the twelfth week; in the third and fourth weeks of experimentation two doses of DMH solution ( $i p)$ were administrated concomitantly with hydroalcoholic solution ( $p o$ ).

The animals of the MPEE group received MPEE solution (po) daily until the twelfth week; and two doses of EDTA ( $i p)$ were administered in the third and fourth weeks, concurrently with MPEE.

In the pre-treatment group, the animals were treated with MPEE ( $p o$ ) for the first 2 weeks (first and second); in the subsequent 2 weeks (third and fourth), DMH was administered (ip) concurrently with the hydroalcoholic solution orally. In the following weeks, only hydroalcoholic solution ( $\mathrm{po}$ ) was administered until the last day of experimentation.

Regarding the simultaneous group, the animals were treated with hydroalcoholic solution ( $p o$ ) for the first 2 weeks (first and second); for the subsequent 2 weeks (third and fourth), MPEE ( $p o$ ) was administered daily, and DMH (ip) twice weekly. From the fifth to twelfth week, the animals resumed receiving hydroalcoholic solution ( $p o$ ).

In the post-treatment group, hydroalcoholic solution was administered ( $p o$ ) daily in the first 4 weeks. In the third and fourth weeks, DMH (ip) was administered twice weekly, and in the next eight weeks (fifth to twelfth), only MPEE was administered ( $p o$ ).

Peripheral blood samples were collected to evaluate the genetic integrity. The collections (via caudal venipuncture) occurred 24 and 48 hafter the last administration of EDTA or DMH, for the comet and micronucleus assays, respectively. The collection of spleen and intestines for evaluating splenic phagocytosis and aberrant crypt foci, respectively, was performed at the end of the 12 th week of experimentation.

For the analysis of biometric parameters, the body weight was assessed at the beginning and end of experiment. At the end, the body weight and the organs (heart, lung, kidney, liver, and spleen) were evaluated.

\section{Biological assays}

\section{Comet assay}

Comet assays were performed according to the procedure described by Oliveira et al. (2013) as follows. Peripheral blood $(20 \mu \mathrm{L})$ was collected ( $24 \mathrm{~h}$ after the last dose of EDTA or $\mathrm{DMH}$ ) into heparinized cryotubes, homogenized with $120 \mu \mathrm{L} \mathrm{1.5 \%} \mathrm{low-melting-point} \mathrm{agarose}$ at $37^{\circ} \mathrm{C}$, and placed onto slides coated with standard $5 \%$ agarose. The slides were covered with glass coverslips and cooled to $4^{\circ} \mathrm{C}$ for $20 \mathrm{~min}$. After coverslip removal, the slides from all

Genetics and Molecular Research 16 (1): gmr16019518 
experiments were immersed in freshly prepared lysis solution composed of $89 \mathrm{~mL}$ stock lysis buffer $(2.5 \mathrm{M} \mathrm{NaCl}, 100 \mathrm{mM}$ EDTA, $10 \mathrm{mM}$ Tris adjusted to $\mathrm{pH} 10$ with solid $\mathrm{NaOH}, 890 \mathrm{~mL}$ distilled water, and $1 \%$ sodium lauroyl sarcosinate), $1 \mathrm{~mL}$ Triton X-100 (Merck, Germany), and $10 \mathrm{~mL}$ dimethyl sulfoxide. The samples were lysed for $1 \mathrm{~h}$ at $4^{\circ} \mathrm{C}$ with protection from light. The slides were then transferred to an electrophoresis tank containing buffer with a $\mathrm{pH}$ of $>13(300 \mathrm{mM} \mathrm{NaOH}$ and $1 \mathrm{mM}$ EDTA prepared from a stock solution of $200 \mathrm{mM}$ EDTA and $10 \mathrm{~N} \mathrm{NaOH}, \mathrm{pH} 10.0$ ) at $4^{\circ} \mathrm{C}$ and incubated for 20 min for DNA denaturation. Electrophoresis was performed at $300 \mathrm{~mA}$ and $25 \mathrm{~V}(1.25 \mathrm{~V} / \mathrm{cm})$ for $20 \mathrm{~min}$. Subsequently, the slides were neutralized with buffer $(0.4 \mathrm{M}$ Tris- $\mathrm{HCl}, \mathrm{pH} 7.5)$ in 3 cycles of $5 \mathrm{~min}$ each, airdried, fixed in absolute ethanol for $10 \mathrm{~min}$, and stored for later analysis. Next, $100 \mu \mathrm{L}$ ethidium bromide $(20 \mathrm{mg} / \mathrm{mL})$ was used for staining. The samples were evaluated at $40 \mathrm{X}$ magnification under a fluorescence microscope (Bioval ${ }^{\circledR}$ Model G 2000A, Brazil) fitted with a 420- to 490$\mathrm{nm}$ excitation filter and a $520-\mathrm{nm}$ barrier filter. In total, 100 cells per animal were visually analyzed, and the comets were classified as follows: class 0 , undamaged cells without tails; class 1 , cells with tails smaller than the nucleoid diameter; class 2, cells with tails 1- to 2-fold the nucleoid diameter; and class 3, cells with tails greater than 2-fold the nucleoid diameter. According to the protocol, apoptotic cells and those with totally fragmented nucleoids were not counted. The total score was calculated by adding the results from the multiplication of the total number of observed cells per injury class by the class value. Statistical analysis was performed with analysis of variance (ANOVA) and the Tukey test $(\mathrm{P}<0.05)$.

\section{Micronucleus assay}

The micronucleus assay development method described by Oliveira et al. (2009) was used. Slides were coated with $20 \mu \mathrm{L}$ acridine orange $(1 \mathrm{mg} / \mathrm{mL})$. Next, $20 \mu \mathrm{L}$ peripheral blood was deposited onto each slide, covered with a coverslip, and stored in a freezer $\left(-20^{\circ} \mathrm{C}\right)$ for a minimum of 7 days. Analysis was performed at 40X magnification under an epifluorescence microscope (Bioval ${ }^{\circledR}$, Model L 2000A, Brazil) with a 420- to 490-nm excitation filter and a $520-\mathrm{nm}$ barrier filter. A total of 2000 cells/animal were analyzed, and statistical analysis was performed with ANOVA and the Tukey test $(\mathrm{P}<0.05)$.

\section{Phagocytosis assay}

Phagocytosis assays were performed according to the procedure described by Schneider et al. (2016). In the twelfth week, after euthanasia, the spleens were collected, and $1 / 3$ of the organ was macerated in saline to obtain a homogenous cell suspension by repeated aspiration with a Pasteur pipette. Then, $100 \mu \mathrm{L}$ of this cell suspension was deposited onto a slide previously coated with acridine orange $(1 \mathrm{mg} / \mathrm{mL})$ covered with a glass coverslip. The slides were stored in a freezer until the time of analysis, performed with a fluorescence microscope (Bioval ${ }^{\circledR}$, Model L 2000A) at 40X magnification, fitted with a 420-490-nm filter and a 520-nm barrier filter. A total of 200 cells/animal were analyzed.

Percentage points were used to calculate the extent of phagocytosis reduction/ increase. For this purpose, the frequency of cells that exhibited evidence of phagocytosis in the negative control group was considered $100 \%$, and the percentage for each associated group was calculated by the rule of three. This calculated value was then subtracted from 100, and the result is presented as the reduction/increase in phagocytic activity in percentage points.

Genetics and Molecular Research 16 (1): gmr16019518 


\section{Aberrant crypt focus assay}

The collected mouse colons and rectums were washed in a physiological buffer solution and then dissected for subsequent fixation in $10 \%$ buffered formalin for a minimum of $24 \mathrm{~h}$. For analysis, each colorectal segment was stained with $10 \%$ methylene blue solution for $10 \mathrm{~min}$ and placed on a slide mucosal side up. Analysis was performed at 10X magnification using a light microscope. The entire mucosa was evaluated to identify and quantify aberrant crypt foci. Aberrant crypt foci were identified using the criteria described by Mauro et al. (2013) as follows. I) In foci with a single crypt, the aberrant crypt is coated in a thick epithelial layer with an elliptical luminal opening at least 2-fold larger than those of the surrounding normal crypts. II) In foci with 2 or more crypts, the aberrant crypts form distinct blocks and occupy an area larger than that occupied by an equal number of crypts of normal morphology. In the latter, no normal crypts separate the aberrant crypts in the foci. Comparison of the aberrant crypt focus test data (total number of foci of aberrant crypts, number of aberrant crypts per foci, and crypt/focus ratio) from the experimental groups was performed with ANOVA and the Tukey test $(\mathrm{P}<0.05)$.

\section{Calculation of percent damage reduction (\%DR)}

The percentage of DMH damage reduction by MPEE was calculated as suggested by Manoharan and Banerjee (1985):

$$
\% \mathrm{DR}=\left[\frac{\text { Mean of positive control }- \text { Mean of associated group }}{\text { Mean of positive control }- \text { Mean of negativecontrol }}\right] \times 100
$$

\section{Statistical analysis}

The results are reported as means \pm standard deviation or as percentages. The data were analyzed using ANOVA or the Tukey test (GraphPad Prism, V. 3.02; Graph-Pad Software Inc., San Diego, CA, USA). The significance level was set at $\mathrm{P}<0.05$ or $\mathrm{P}>0.05$.

\section{RESULTS}

\section{Biometrical parameters}

The animal's initial and final weights and weight gain were not significantly different $(\mathrm{P}>0.05)($ Table 1). The same occurred with the absolute weight of the hearts, lungs, kidneys, and spleens, and with the relative weight of the hearts, lungs, livers, and spleens (Table 2). On assessing the absolute weight of the livers, a reduction $(\mathrm{P}<0.05)$ was observed in MPEE, simultaneous, and post-treatment groups. It was also found increased $(\mathrm{P}<0.05)$ relative weight of the kidneys in the post-treatment group, when compared with the others (Table 3). Only the liver absolute weight changed significantly.

This difference was not seen in the relative weight, which suggests the absence of toxicity. Nevertheless the relative weight of the kidneys in the post-treatment protocol presented a statistically significant increase, and this fact needs to be better evaluated in future trials on kidney function. 
Table 1. Means \pm standard error of initial/final weight and weight gain during the experimental period.

\begin{tabular}{l|c|c|c}
\hline Experimental group & Initial weight $(\mathrm{g})$ & Final weight $(\mathrm{g})$ & Weight gain $(\mathrm{g})$ \\
\hline Control & $41.42 \pm 0.92$ & $41.14 \pm 0.59$ & $-0.28 \pm 1.04$ \\
\hline DMH & $38.28 \pm 0.60$ & $40.57 \pm 0.29$ & $2.28 \pm 0.42$ \\
\hline MPEE & $39.42 \pm 0.86$ & $40.42 \pm 0.36$ & $1.00 \pm 1.11$ \\
\hline Pre-treatment & $38.71 \pm 0.56$ & $40.57 \pm 0.20$ & $1.85 \pm 0.45$ \\
\hline Simultaneous & $38.28 \pm 1.16$ & $38.28 \pm 1.44$ & $0.00 \pm 1.23$ \\
\hline Post-treatment & $39.85 \pm 0.59$ & $38.85 \pm 0.79$ & $-1.00 \pm 0.57$ \\
\hline
\end{tabular}

The differences between means are not statistically significant (ANOVA/Tukey test; $\mathrm{P}>0.05$ ).

Table 2. Means \pm standard error of absolute organ weights.

\begin{tabular}{l|c|c|c|c|c}
\hline \multirow{2}{*}{ Experimental groups } & \multicolumn{5}{|c}{ Total weight $(\mathrm{g})$} \\
\cline { 2 - 6 } & Heart & Lungs & Kidneys & Liver & Spleen \\
\hline Control & $0.2200 \pm 0.0104^{\mathrm{a}}$ & $0.2588 \pm 0.0082^{\mathrm{a}}$ & $0.5500 \pm 0.0111^{\mathrm{a}, \mathrm{b}}$ & $2.2885 \pm 0.0613^{\mathrm{b}, \mathrm{c}}$ & $0.1428 \pm 0.0086^{\mathrm{a}}$ \\
\hline DMH & $0.1842 \pm 0.0071^{\mathrm{a}}$ & $0.2341 \pm 0.0137^{\mathrm{a}}$ & $0.6257 \pm 0.0130^{\mathrm{b}}$ & $2.2885 \pm 0.0623^{\mathrm{b}, \mathrm{c}}$ & $0.1714 \pm 0.0040^{\mathrm{a}}$ \\
\hline MPEE & $0.2300 \pm 0.0111^{\mathrm{a}}$ & $0.2823 \pm 0.0130^{\mathrm{a}}$ & $0.5500 \pm 0.0302^{\mathrm{a}, \mathrm{b}}$ & $1.9342 \pm 0.0632^{\mathrm{a}}$ & $0.1500 \pm 0.0059^{\mathrm{a}}$ \\
\hline Pre-treatment & $0.2485 \pm 0.0131^{\mathrm{a}}$ & $0.2851 \pm 0.0174^{\mathrm{a}}$ & $0.5971 \pm 0.0180^{\mathrm{a}, \mathrm{b}}$ & $2.0742 \pm 0.0599^{\mathrm{a}, \mathrm{b}}$ & $0.1485 \pm 0.0059^{\mathrm{a}}$ \\
\hline Simultaneous & $0.1914 \pm 0.0112^{\mathrm{a}}$ & $0.2776 \pm 0.0101^{\mathrm{a}}$ & $0.5214 \pm 0.0193^{\mathrm{a}}$ & $1.9528 \pm 0.0546^{\mathrm{a}}$ & $0.1542 \pm 0.0123^{\mathrm{a}}$ \\
\hline Post-treatment & $0.1957 \pm 0.0151^{\mathrm{a}}$ & $0.2895 \pm 0.0139^{\mathrm{a}}$ & $0.6342 \pm 0.0285^{\mathrm{b}, \mathrm{c}}$ & $1.9228 \pm 0.0675^{\mathrm{a}}$ & $0.1614 \pm 0.0055^{\mathrm{a}}$ \\
\hline
\end{tabular}

Different letters indicate statistically significant differences (ANOVA/Tukey test; $\mathrm{P}<0.05$ ).

Table 3. Means \pm standard error of relative organ weights.

\begin{tabular}{l|c|c|c|c|c}
\hline \multirow{2}{*}{ Experimental groups } & \multicolumn{5}{|c}{ Relative weight $(\mathrm{g})$} \\
\cline { 2 - 6 } & Heart & Lungs & Kidneys & Liver & Spleen \\
\hline Control & $0.0053 \pm 0.0002^{\mathrm{a}, \mathrm{b}}$ & $0.0062 \pm 0.0002^{\mathrm{a}, \mathrm{b}}$ & $0.0133 \pm 0.0003^{\mathrm{a}}$ & $0.0557 \pm 0.0020^{\mathrm{a}, \mathrm{b}}$ & $0.0034 \pm 0.0002^{\mathrm{a}}$ \\
\hline DMH & $0.0045 \pm 0.0002^{\mathrm{a}}$ & $0.0057 \pm 0.0003^{\mathrm{a}}$ & $0.0154 \pm 0.0003^{\mathrm{a}, \mathrm{b}}$ & $0.0564 \pm 0.0018^{\mathrm{b}}$ & $0.0042 \pm 0.0000^{\mathrm{a}}$ \\
\hline MPEE & $0.0056 \pm 0.0002^{\mathrm{a}, \mathrm{b}}$ & $0.0070 \pm 0.0003^{\mathrm{a}, \mathrm{b}}$ & $0.0136 \pm 0.0008^{\mathrm{a}}$ & $0.0478 \pm 0.0016^{\mathrm{a}}$ & $0.0037 \pm 0.0002^{\mathrm{a}}$ \\
\hline Pre-treatment & $0.0061 \pm 0.0003^{\mathrm{b}}$ & $0.0070 \pm 0.0004^{\mathrm{a}, \mathrm{b}}$ & $0.0147 \pm 0.0004^{\mathrm{a}, \mathrm{b}}$ & $0.0511 \pm 0.0015^{\mathrm{a}, \mathrm{b}}$ & $0.0036 \pm 0.0001^{\mathrm{a}}$ \\
\hline Simultaneous & $0.0050 \pm 0.0003^{\mathrm{a}, \mathrm{b}}$ & $0.0072 \pm 0.0003^{\mathrm{b}}$ & $0.0136 \pm 0.0005^{\mathrm{a}}$ & $0.0512 \pm 0.0015^{\mathrm{a}, \mathrm{b}}$ & $0.0040 \pm 0.0003^{\mathrm{a}}$ \\
\hline Post-treatment & $0.0050 \pm 0.0003^{\mathrm{a}, \mathrm{b}}$ & $0.0074 \pm 0.0004^{\mathrm{b}}$ & $0.0163 \pm 0.0008^{\mathrm{b}}$ & $0.0497 \pm 0.0025^{\mathrm{a}, \mathrm{b}}$ & $0.0041 \pm 0.0001^{\mathrm{a}}$ \\
\hline
\end{tabular}

Different letters indicate statistically significant differences (ANOVA/Tukey test; $\mathrm{P}<0.05$ ).

\section{Genetic integrity and DNA damage prevention}

The comet and micronucleus assays showed that MPEE has no genotoxic or mutagenic activity since the frequency of damaged and/or micronucleated cells, respectively, did not differ from control (Tables 4 and 5).

Antigenotoxic activity was observed in the pre-treatment and simultaneous treatment protocols and the \%DRs were 81.88 and 93.12, respectively (Table 4). All protocols showed antimutagenic activity and the \%DRs were $77.09,94.41$, and 78.21 for the pre-treatment, simultaneous treatment, and post-treatment groups, respectively (Table 5).

Table 4. Means \pm standard error, frequency of damaged cells, and distribution between damage classes.

\begin{tabular}{|c|c|c|c|c|c|c|c|}
\hline \multirow[t]{2}{*}{ Experimental group } & \multirow[t]{2}{*}{ Damaged cells } & \multicolumn{4}{|c|}{ Damage classes } & \multirow[t]{2}{*}{ Score } & \multirow[t]{2}{*}{$\% \mathrm{DR}$} \\
\hline & & 0 & 1 & 2 & 3 & & \\
\hline \multicolumn{8}{|l|}{ Genotoxicity } \\
\hline Control & $0.58 \pm 0.29^{\mathrm{a}}$ & $99.42 \pm 0.29^{\mathrm{a}}$ & $0.28 \pm 0.18^{\mathrm{a}}$ & $0.28 \pm 0.18^{\mathrm{a}}$ & $0.00 \pm 0.00^{\mathrm{a}}$ & $0.85 \pm 0.45^{\mathrm{a}}$ & \\
\hline DMH & $23.43 \pm 1.28^{\mathrm{b}}$ & $75.57 \pm 1.28^{\mathrm{b}}$ & $14.00 \pm 1.39^{\mathrm{b}}$ & $9.85 \pm 0.40^{\mathrm{b}}$ & $0.57 \pm 0.36^{\mathrm{a}}$ & $32.42 \pm 1.66^{\mathrm{b}}$ & \\
\hline MPEE & $1.58 \pm 0.57^{\mathrm{a}}$ & $98.42 \pm 0.57^{\mathrm{a}}$ & $1.14 \pm 0.40^{\mathrm{a}}$ & $0.28 \pm 0.28^{\mathrm{a}}$ & $0.14 \pm 0.14^{\mathrm{a}}$ & $2.14 \pm 1.05^{\mathrm{a}}$ & \\
\hline \multicolumn{8}{|l|}{ Antigenotoxicity } \\
\hline Pre-treatment & $4.72 \pm 0.83^{\mathrm{a}}$ & $95.28 \pm 0.83^{\mathrm{a}}$ & $4.28 \pm 0.60^{\mathrm{a}}$ & $0.42 \pm 0.29^{\mathrm{a}}$ & $0.00 \pm 0.00^{\mathrm{a}}$ & $5.14 \pm 1.10^{\mathrm{a}}$ & 81.88 \\
\hline Simultaneous & $2.15 \pm 0.59^{\mathrm{a}}$ & $97.85 \pm 0.59^{\mathrm{a}}$ & $1.71 \pm 0.36^{\mathrm{a}}$ & $0.42 \pm 0.29^{\mathrm{a}}$ & $0.00 \pm 0.00^{\mathrm{a}}$ & $2.57 \pm 0.86^{\mathrm{a}}$ & 93.12 \\
\hline Post-treatment & $24.29 \pm 3.24^{\mathrm{b}}$ & $75.71 \pm 3.24^{\mathrm{b}}$ & $16.14 \pm 1.69^{\mathrm{b}}$ & $7.28 \pm 1.84^{\mathrm{b}}$ & $0.85 \pm 0.34^{\mathrm{b}}$ & $33.28 \pm 5.55^{\mathrm{b}}$ & -3.73 \\
\hline
\end{tabular}

$\%$ DR: percent damage reduction. Different letters indicate statistically significant differences (ANOVA/Tukey test; P $<0.05)$.

Genetics and Molecular Research 16 (1): gmr16019518 
Table 5. Total frequency and means \pm standard error of the micronucleus frequency.

\begin{tabular}{l|c|c|c}
\hline \multirow{2}{*}{ Experimental group } & Micronucleus frequency & Mean \pm SE & TDR \\
\cline { 2 - 4 } & \multicolumn{3}{c}{ T2 } \\
\hline Mutagenicity & 107 & $15.28 \pm 1.04^{\mathrm{a}}$ & - \\
\hline Control & 286 & $40.85 \pm 1.90^{\mathrm{c}}$ & - \\
\hline DMH & 142 & $20.28 \pm 1.14^{\mathrm{a}, \mathrm{b}}$ & - \\
\hline MPEE & \multicolumn{3}{c}{} \\
\hline Antimutagenicity & 148 & $21.14 \pm 1.17^{\mathrm{b}}$ & 77.09 \\
\hline Pre-treatment & 117 & $16.71 \pm 0.64^{\mathrm{a}, \mathrm{b}}$ & 94.41 \\
\hline Simultaneous & 146 & $20.85 \pm 1.24^{\mathrm{b}}$ & 78.21 \\
\hline Post-treatment & \multicolumn{3}{c}{} \\
\hline
\end{tabular}

$\% \mathrm{DR}$ : percent damage reduction; SE: standard error. Different letters indicate statistically significant differences (ANOVA/Tukey test; $\mathrm{P}<0.05)$.

\section{Splenic phagocytosis}

Regarding splenic phagocytosis activity, the DMH, MPEE, and pre-treatment groups presented reduction of cells that exhibited evidence of phagocytosis of 3.80, 28.37, and 30.45 percentage points, respectively. On the other hand, in the simultaneous and post-treatment groups, an increase in the percentage points of cells that exhibited evidence of phagocytosis ranging from 39.10 to $94.82 \%$ was observed (Table 6).

Table 6. Number of analyzed cells, means \pm standard error, and cell percentage with splenic phagocytosis evidence in mice.

\begin{tabular}{|c|c|c|c|}
\hline \multirow[t]{2}{*}{ Experimental group } & & \multicolumn{2}{|c|}{ Phagocytosis evidence } \\
\hline & Analyzed cells & Mean \pm SE & Percent (\%) \\
\hline Control & 1400 & $41.28 \pm 1.61^{\mathrm{b}}$ & 20.64 \\
\hline $\mathrm{DMH}$ & 1400 & $39.71 \pm 2.03^{\mathrm{b}}$ & 19.85 \\
\hline MPEE & 1400 & $29.57 \pm 1.49^{\mathrm{a}}$ & 14.78 \\
\hline Pre-treatment & 1400 & $28.71 \pm 1.70^{\mathrm{a}}$ & 14.35 \\
\hline Simultaneous & 1400 & $57.42 \pm 1.52^{\mathrm{c}}$ & 28.71 \\
\hline Post-treatment & 1400 & $80.42 \pm 2.01^{\mathrm{d}}$ & 40.21 \\
\hline
\end{tabular}

SE: standard error. Different letters indicate statistically significant differences (ANOVA/Tukey test; $\mathrm{P}<0.05$ ).

\section{Reduction in the formation of aberrant crypt foci}

MPEE did not cause the formation of aberrant crypt focus, rather it avoided the formation of this tumor biomarker. The \%DRs were $62.13,86.40$, and 95.14 for the pretreatment, simultaneous treatment, and post-treatment protocols, respectively (Table 7).

Table 7. Number, distribution, and percent damage reduction of aberrant crypt foci.

\begin{tabular}{l} 
Experimental group \\
\cline { 2 - 6 }
\end{tabular}

AC: aberrant crypt; AV: absolute values; SE: standard error. Different letters indicate statistically significant differences (ANOVA/Tukey test; $\mathrm{P}<0.05$ ).

Genetics and Molecular Research 16 (1): gmr16019518 


\section{DISCUSSION}

The toxicological (Vasconcelos et al., 2007) and toxicogenetic (David et al., 2014) evaluations are important as the indiscriminate use of herbs and medicinal plants constitutes a public health issue. In addition, the control of commercialization exerted by official agencies and the studies to guarantee the safe use of plants are incipient regarding medicinal plants.

M. polymorphum is a plant often used in popular medicine for the treatment of inflammations (Bueno et al., 2005; Arambarri et al., 2008). Two studies were found about its effects on DNA, one with salmonella (Horn and Vargas, 2008) and another with female pregnant mice (David et al, 2014). The latter indicates that MPEE is neither mutagenic nor teratogenic, which suggests that the use of this medicinal plant is safe even during pregnancy. Our findingsconfirm the compound safety and innovatively show that MPEE is neither genotoxic nor mutagenic in male mice even when administered for 8 consecutive weeks, a period longer than other protocols described for this plant.

The antiproliferative and cytotoxic effects of $M$. polymorphum have been described on U251 tumor lineage (glioma), UACC-62 (melanoma), MCF-7 (breast cancer), NCI-ADR/ RES (drug-resistant ovarian cancer), 786.0 (kidney), NCI-H460 (lung), PC-3 (prostate), OVCAR-3 (ovary), HT-29 (colon), and K562 (leukemia) (Strapasson et al., 2012). Martins et al. (2015) also demonstrated a reduced growth of the Walker 256 tumor. The present study is the first to describe the chemopreventive effects of this plant and its ability to prevent chemical carcinogenesis in the intestine.

According to Steward and Brown (2013), chemoprevention is the ability that natural or synthetic products have to avoid cancer and/or suppress or reverse carcinogenesis in its early stages. Therefore, short-term tests, such as comet and micronucleus assays, are successfully employed to screen for anti-cancer substances. By means of these tests, the present study demonstrated the efficiency of MPEE in avoiding genotoxic and mutagenic damage, thus confirming the chemopreventive effect of the extract ( $94.41 \%$ damage reduction). This result pointed to the need for a sequential test with medium or long-term studies that would evaluate tumor biomarkers or even installed neoplasia (Maurin et al., 2007). Given the above, we have chosen a medium-term test, the aberrant crypt focus assay (Bazo et al., 2002; Agner et al., 2005).

The multi-stage chemical carcinogenesis induced by DMH is one of the most widely used models for intestinal cancer study (Rodrigues et al., 2002). The disease is generally formed from cells that have undergone permanent and irreversible DNA damage detected by the micronucleus assay, for example. These mutations may remain dormant for long periods, including during the stage next to initiation, the promotion phase. In this phase, the cells are induced to proliferate and will result in precancerous lesions (Pitot and Dragan, 1991; Pitot, 1993). Next, in the progression phase, the neoplasia is phenotypically expressed and can be histologically detected. Its characteristic is the genetic/genomic instability which, among other features, results in a high-proliferation rate, favoring the invasion of adjacent tissues and the metastasis. In this phase, biochemical changes are also observed that enable the clinical manifestation of the phenomenon, the last step of multi-stage carcinogenesis (Pitot, 1989). The development of these changes in the intestinal mucosa is associated with inflammation.

DMH is classified as a pro-carcinogen agent, that is, it requires metabolic activation to become an active carcinogen (LaMont and O'Gorman, 1978), and the activation mainly occurs in the liver, with oxidation of DMH in azomethane and, subsequently, in azoxymethane, which, in turn, is converted into methyl-azoxymethane (Weisburger, 1971; LaMont and

Genetics and Molecular Research 16 (1): gmr16019518 
O'Gorman, 1978). At body temperature, methyl-azoxymethane is an unstable compound that undergoes decomposition spontaneously, giving rise to formaldehyde, water, nitrogen, and methyl diazonium, an alkylating agent that introduces a reactive carbonic ion capable of reacting with DNA, RNA, and proteins (Weisburger, 1971). The DMH carcinogenic activity therefore involves DNA methylation into colonic epithelial cells (Hawks et al., 1974). The methyl-azoxymethane also undergoes an enzyme-metabolizing process by the action of the alcohol dehydrogenase enzyme (present in the liver and colon, and at low concentrations in the jejunum and ileum), becoming methyl azoxy formaldehyde (Grab and Zedeck, 1977).

In addition, the administration of DMH in rodents triggers a mild inflammatory reaction and an increased cell proliferation in the colonic mucosa. Its successive application results in continuous proliferation, with an increased number of cells in the DNA replication phase (Wargovich et al., 1983), which triggers progressive hyperplasia of the crypt and hypertrophy of the mucosa (Richards, 1977). DMH has then been shown to cause damage to the DNA synthesis, resulting in a pro-mutagenic lesion at the $\mathrm{O}^{6}$-methylguanine, which, as is known, induces GC $\rightarrow$ AT transitions. Such mutations are typically found in various colorectal cancer-related genes (Diehl et al., 2006).

The aforementioned facts explain the occurrence of genotoxic damage (mean 23.43 \pm 1.28 injured cells), mutagenic damage (mean $40.85 \pm 1.90$ micronucleated cells), and intestinal carcinogenesis markers (mean $14.85 \pm 1.26$ aberrant crypt foci). The administration of MPEE, a proven anti-inflammatory (Piornedo et al., 2011), reduced all biomarkers in both short-term trials (comet and micronucleus assays) and the medium-term test (aberrant crypt foci). In the latter, the $\% \mathrm{DR}$ reached 95.15 , which presents the anticarcinogenic activity of $M$. polymorphum also in models of intestinal chemical carcinogenesis.

The chemopreventive (also called antimutagenic) compounds generally act by desmutagenesis and bioantimutagenesis (Waters et al., 1990), and can directly act on the damage-inducing compound, mainly by chelating it or by inactivating it enzymatically, or even by working on the repairing enzymes, favoring the correction of the damage caused on the DNA by the carcinogenic agent (Kada et al., 1982; Kada and Shimoi, 1987).

Thus, based on the results of the micronucleus assay, it is supposed that the MPEE can act by both desmutagenesis and bioantimutagenesis since the \%DRs were high in all protocols; and the pre-treatment and post-treatment ones indicate desmutagenesis and bioantimutagenesis, respectively (Ishii et al., 2011; Pesarini et al., 2013).

The reduction in circulating micronucleated cells can occur by splenic phagocytosis (Bazo et al., 2002; Ishii et al, 2011), reason why this assay was also carried out in our study.

The administration of MPEE caused a discrete increase in the frequency of phagocytosis in the simultaneous and post-treatment protocols; when administered alone, the phagocytic activity is not increased. These data allow us to infer, therefore, that the main event related to the mutagenic damage reduction is chemoprevention, rather than the phagocytic process.

Considering the above, MPEE is not mutagenic, has chemopreventive potential it is able to reduce the incidence of aberrant cript foci. These data suggest that the extract has the potential for prospecting compounds for cancer prevention and treatment.

\section{ACKNOWLEDGMENTS}

Research supported by Fundação de Apoio ao Desenvolvimento do Ensino, Ciência e Tecnologia do Estado de Mato Grosso do Sul - FUNDECT; Coordenação de Aperfeiçoamento

Genetics and Molecular Research 16 (1): gmr16019518 
de Pessoal de Nível Superior - CAPES, and Conselho Nacional de Desenvolvimento Científico e Tecnológico - CNPq.

\section{REFERENCES}

Agner AR, Bazo AP, Ribeiro LR and Salvadori DM (2005). DNA damage and aberrant crypt foci as putative biomarkers to evaluate the chemopreventive effect of annatto (Bixa orellana L.) in rat colon carcinogenesis. Mutat. Res. 582: 146-154. http://dx.doi.org/10.1016/j.mrgentox.2005.01.009

American Cancer Society (ACS) (2016). Avaliable at [http://www.cancer.org/acs/groups/content/@research/documents/ document/acspc-047079.pdf]. Accessed July 19, 2016.

Arambarri AM, Freire SE, Colares MN, Bayón ND, et al. (2008). Leaf anatomy of medicinal shrubs and trees from Misiones forest of the Paranaense Province (Argentina): Part 2. Bol. Soc. Argent. Bot. 43: 31-60.

Bazo AP, Rodrigues MA, Sforcin JM, de Camargo JL, et al. (2002). Protective action of propolis on the rat colon carcinogenesis. Teratog. Carcinog. Mutagen. 22: 183-194. http://dx.doi.org/10.1002/tcm.10011

Bueno RB, Castilho RO, da Costa RB, Pott A, et al. (2005). Medicinal plants used by the Kaiowá and Guarani indigenous populations in the Caarapó Reserve, Mato Grosso do Sul, Brazil. Acta Bot. Bras. 19: 39-44. http://dx.doi.org/10.1590/ $\underline{\mathrm{S} 0102-33062005000100005}$

David Nd, Mauro M de O, Gonçalves CA, Pesarini JR, et al. (2014). Gochnatia polymorpha ssp. floccosa: bioprospecting of an anti-inflammatory phytotherapy for use during pregnancy. J. Ethnopharmacol. 154: 370-379. http://dx.doi. org/10.1016/j.jep.2014.04.005

Diehl D, Oesterle D, Elmlinger MW, Hoeflich A, et al. (2006). IGF-II transgenic mice display increased aberrant colon crypt multiplicity and tumor volume after 1,2-dimethylhydrazine treatment. J. Carcinog. 5: 24. http://dx.doi. org/10.1186/1477-3163-5-24

Diniz FF, Perondi F and Gonçalves JÁ (2012). Epidemiologia e fatores de risco. In: Tratado de Coloproctologia (de Campos FGCM, Regadas FSP and Pinho M de SL, eds.). 1st edn. Editora Atheneu, São Paulo, 303-311.

Grab DJ and Zedeck MS (1977). Organ-specific effects of the carcinogen methylazoxymethanol related to metabolism by nicotinamide adenine dinucleotide-dependent dehydrogenases. Cancer Res. 37: 4182-4189.

Hawks A, Hicks RM, Holsman JW and Magee PN (1974). Morphological and biochemical effects of 1,2-dimethylhydrazine and 1-methylhydrazine in rats and mice. Br. J. Cancer 30: 429-439. http://dx.doi.org/10.1038/bjc.1974.217

Horn RC and Vargas VM (2008). Mutagenicity and antimutagenicity of teas used in popular medicine in the salmonella/ microsome assay. Toxicol. In Vitro 22: 1043-1049. http://dx.doi.org/10.1016/j.tiv.2007.12.014

Hu T, Li LF, Shen J, Zhang L, et al. (2015). Chronic inflammation and colorectal cancer: the role of vascular endothelial growth factor. Curr. Pharm. Des. 21: 2960-2967. http://dx.doi.org/10.2174/1381612821666150514104244

Instituto Nacional de Câncer - INCA (2016). Available at [http://www.inca.gov.br/bvscontrolecancer/publicacoes/edicao/ Estimativa_2016.pdf]. Accessed July 19, 2016.

Ishii PL, Prado CK, Mauro M de O, Carreira CM, et al. (2011). Evaluation of Agaricus blazei in vivo for antigenotoxic, anticarcinogenic, phagocytic and immunomodulatory activities. Regul. Toxicol. Pharmacol. 59: 412-422. http:// dx.doi.org/10.1016/j.yrtph.2011.01.004

Kada T and Shimoi K (1987). Desmutagens and bio-antimutagens - their modes of action. BioEssays 7: 113-116. http:// dx.doi.org/10.1002/bies.950070305

Kada T, Inoue T and Namiki N (1982). Environmental desmutagens and antimutagens. In: Environmental Mutagenesis and Plant Biology (Klekowski EJ, ed.). Praeger, New York, 137-151.

Labianca R, Nordlinger B, Beretta GD, Mosconi S, et al.; ESMO Guidelines Working Group (2013). Early colon cancer: ESMO Clinical Practice Guidelines for diagnosis, treatment and follow-up. Ann. Oncol. 24 (Suppl 6): vi64-vi72. http://dx.doi.org/10.1093/annonc/mdt354

LaMont JT and O'Gorman TA (1978). Experimental colon cancer. Gastroenterology 75: 1157-1169.

Manoharan K and Banerjee MR (1985). beta-Carotene reduces sister chromatid exchanges induced by chemical carcinogens in mouse mammary cells in organ culture. Cell Biol. Int. Rep. 9: 783-789. http://dx.doi.org/10.1016/0309$\underline{1651(85) 90096-7}$

Martins GG, Lívero FA, Stolf AM, Kopruszinski CM, et al. (2015). Sesquiterpene lactones of Moquiniastrum polymorphum subsp. floccosum have antineoplastic effects in Walker-256 tumor-bearing rats. Chem. Biol. Interact. 228: 46-56. http://dx.doi.org/10.1016/j.cbi.2015.01.018

Maurin N, Forgue-Lafitte ME, Levy P, Zimber A, et al. (2007). Progression of tumors arising from large ACF is associated with the MUC5AC expression during rat colon MNNG carcinogenis. Int. J. Cancer 120: 477-483. http://dx.doi. $\underline{\operatorname{org} / 10.1002 / \mathrm{ijc} .22302}$

Genetics and Molecular Research 16 (1): gmr16019518 
Mauro MO, Monreal MTFD, Silva MTP, Pesarini JR, et al. (2013). Evaluation of the antimutagenic and anticarcinogenic effects of inulin in vivo. Genet. Mol. Res. 12: 2281-2293. http://dx.doi.org/10.4238/2013.July.8.9

Oliveira RJ, Baise E, Mauro M de O, Pesarini JR, et al. (2009). Evaluation of chemopreventive activity of glutamine by the comet and the micronucleus assay in mice's peripheral blood. Environ. Toxicol. Pharmacol. 28: 120-124. http:// dx.doi.org/10.1016/j.etap.2009.03.008

Oliveira RJ, Salles MJS, da Silva AF, Kanno TYN, et al. (2013). In vivo evaluation of the antimutagenic and antigenotoxic effects of $\beta$-glucan extracted from Saccharomyces cerevisiae in acute treatment with multiple doses. Genet. Mol. Biol. 36: 413-424. http://dx.doi.org/10.1590/S1415-47572013005000028

Pesarini JR, Zaninetti PT, Mauro MO, Carreira CM, et al. (2013). Antimutagenic and anticarcinogenic effects of wheat bran in vivo. Genet. Mol. Res. 12: 1646-1659. http://dx.doi.org/10.4238/2013.May.14.5

Piornedo RdosR, de Souza P, Stefanello MÉ, Strapasson RL, et al. (2011). Anti-inflammatory activity of extracts and 11,13-dihydrozaluzanin C from Gochnatia polymorpha ssp. floccosa trunk bark in mice. J. Ethnopharmacol. 133: 1077-1084. http://dx.doi.org/10.1016/j.jep.2010.11.040

Pitot HC (1989). Progression: the terminal stage in carcinogenesis. Jpn. J. Cancer Res. 80: 599-607. http://dx.doi. org/10.1111/j.1349-7006.1989.tb01683.x

Pitot HC (1993). The molecular biology of carcinogenesis. Cancer 72 (Suppl): 962-970. http://dx.doi.org/10.1002/10970142(19930801)72:3+<962::AID-CNCR2820721303>3.0.CO;2-H

Pitot HC and Dragan YP (1991). Facts and theories concerning the mechanisms of carcinogenesis. FASEB J. 5: 2280-2286.

Richards TC (1977). Early changes in the dynamics of crypt cell populations in mouse colon following administration of 1,2-dimethylhydrazine. Cancer Res. 37: 1680-1685.

Rodrigues MA, Silva LA, Salvadori DM, De Camargo JL, et al. (2002). Aberrant crypt foci and colon cancer: comparison between a short- and medium-term bioassay for colon carcinogenesis using dimethylhydrazine in Wistar rats. Braz. J. Med. Biol. Res. 35: 351-355. http://dx.doi.org/10.1590/S0100-879X2002000300010

Schneider BUC, Meza A, Beatriz A, Pesarini JR, et al. (2016). Cardanol: toxicogenetic assessment and its effects when combined with cyclophosphamide. Genet. Mol. Biol. 39: 279-289. http://dx.doi.org/10.1590/1678-4685GMB-2015-0170

Steward WP and Brown K (2013). Cancer chemoprevention: a rapidly evolving field. Br. J. Cancer 109: 1-7. http://dx.doi. org/10.1038/bjc.2013.280

Strapasson RL, Cervi AC, Carvalho JE, Ruiz AL, et al. (2012). Bioactivity-guided isolation of cytotoxic sesquiterpene lactones of Gochnatia polymorpha ssp. floccosa. Phytother. Res. 26: 1053-1056. http://dx.doi.org/10.1002/ptr.3693

Vasconcelos THC, Modesto-Filho J, Diniz MFFM, Santos HB, et al. (2007). Acute pre-clinical toxicological study with the hydroalcoholic extract of the leaves of Cissus sicyoides L. (Vitaceae). Rev. Bras. Farmacogn. 17: 583-591.

Wargovich MJ, Goldberg MT, Newmark HL and Bruce WR (1983). Nuclear aberrations as a short-term test for genotoxicity to the colon: evaluation of nineteen agents in mice. J. Natl. Cancer Inst. 71: 133-137.

Waters MD, Brady AL, Stack HF and Brockman HE (1990). Antimutagenicity profiles for some model compounds. Mutat. Res. 238: 57-85. http://dx.doi.org/10.1016/0165-1110(90)90039-E

Weisburger JH (1971). Colon carcinogens: their metabolism and mode of action. Cancer 28: 60-70. http://dx.doi. org/10.1002/1097-0142(197107)28:1<60::AID-CNCR2820280113>3.0.CO;2-U

West NP, Kobayashi H, Takahashi K, Perrakis A, et al. (2012). Understanding optimal colonic cancer surgery: comparison of Japanese D3 resection and European complete mesocolic excision with central vascular ligation. J. Clin. Oncol. 30: 1763-1769. http://dx.doi.org/10.1200/JCO.2011.38.3992

World Health Organization (WHO) (2016). Available at [http://globocan.iarc.fr/Pages/fact_sheets_cancer.aspx]. Accessed July 19, 2016.

Genetics and Molecular Research 16 (1): gmr16019518 